\title{
Detection of qnr genes in ESBLs producing and non-producing coliforms
}

Mohammed T. Mahmood *
Basima A. Abdullah **

\begin{abstract}
Background and objectives: The discovery of plasmid-mediated quinolone resistance (PMQR) in the late 1990's added a new dimension to quinolone resistance. During the last years, the occurrence of extended-spectrum- $\beta$-lactameses (ESBLs) and (PMQR) within coliforms group has gained particular attention. The objective of this study was to determine the prevalence of plasmid-mediated fluoroquinolone resistance genes in ESBL-producing coliforms

Materials and method: One hundred and seventy three clinical samples collected from both gender , (110) from urinary tract infections ( UTIs ), and (63) from patients with diabetic foot infections ( DFIs ) who visited or admitted to AL- Salam General Teaching Hospital and AL- Wafa'a center for diabetic patients in Mosul city of Ninavah province / Iraq from April 2013 to February 2014. The isolates were identified to species level depended on morphological, biochemical and physiological tests and confirmed by RapID ${ }^{\mathrm{TM}}$ ONE system (Remel \USA).

Results: The results showed the majority of them were resistant to most antibiotics. Resistance was observed most often to nalidixic acid (85.9\%)followed by norfloxacin $(70.5 \%)$ and ciprofloxacin $(67 \%)$. All ciprofloxacin resistant isolates were tested for their ability to produce the extended spectrum $\beta$ lactamase (ESBL) enzymes using the double disk synergy test (DDST). Out of the total (57) ciprofloxacin resistant coliforms tested, (66.7\%) were ESBL producers. Ciprofloxacin resistant coliforms species were conducted for PCR to investigate the presence of $q n r$ genes. Out of (57) ciprofloxacin resistant spp. qnrB gene (469 bp) was detected in 14(24.6\%) spp. while none of the species had $q n r A$ and $q n r S$ genes in our study. The results also revealed that $q n r B$ gene was found in all (100\%) of ESBL-producing E. coli and $K$. pneumoniae spp.
\end{abstract}

Keywords: Ciprofloxacin resistance, qnr genes, Coliforms

\section{INTRODUCTION}

Quinolones are widely used to treat clinical infections in both in and out patients ; therefore a survey of quinolone resistance would be especially useful. Their use now accounts for about (11\%) of overall prescriptions of antimicrobials in human medicine and one of them , ciprofloxacin is the most used antibiotic in the world (Lyonga et al., 2014 and Tarchouna et al., 2015).

Quinolone resistance was for a long time considered to be entirely mediated by mutations in chromosomal genes encoding quinolone targets (that is, DNA gyrase and topoisomerase IV) and/or in regulatory genes of outermembrane proteins or efflux pumps . Plasmid carrying $q n r$ genes have been found to transmit quinolone resistance. These genes encode pentapeptide repeat proteins that block the action of ciprofloxacin on bacterial DNA gyrase and topoisomerase IV (Rushdy et al., 2013 and Al - Marjani et al., 2015 ).

The discovery of plasmid-mediated quinolone resistance (PMQR) in the late 1990's added a new dimension to quinolone resistance.
During the last years, the occurrence of extended-spectrum- $\beta$-lactameses (ESBLs) and (PMQR) within coliforms group has gained particular attention. ESBL and $q n r$ genes can be carried either on the same plasmid or on different plasmids within the same isolate (Kim et al., 2010 and Raei et al., 2014). Therefore, plasmid-mediated resistance to fluoroquinolones among ESBL-producing coliforms is alarming as it facilitates therapy failure (Vali et al., 2015).The objective of this study was to determine the prevalence of plasmid-mediated fluoroquinolone resistance genes in ESBLproducing coliforms.

\section{MATERIAL AND METHOD}

\section{Bacteriological samples}

A total of 173 bacteriological samples were collected from patients ( 110 urine samples and 63 diabetic foot infection samples ) of both gender who visited or admitted to AL- Salam General Teaching Hospital and AL- Wafa'a center for diabetic patients in Mosul city of Ninavah province / Iraq from April 2013 to February 2014 . Samples were transported quickly by sterile transport media and sterile cotton swabs to the laboratory for culturing on 
MacConky agar and Blood agar. The isolates were identified to species level depended on morphological, biochemical and physiological tests and confirmed by RapID $^{\mathrm{TM}}$ ONE system (Remel \USA).

\section{Detection of Extended - Spectrum B - Lactamase ( ESBLs )}

The test was done by using the double disk synergy test (Ahmed et al ., 2013). The organism to be tested was spread onto a Mueller - Hinton agar plate as in the standard disk diffusion method . Four antibiotic disks are used including Amoxycillin / Clavulanic acid 20 / 10 $\mu \mathrm{g} / \mathrm{disk}$, Ceftazidime , Ceftriaxone , and Cefotaxime $30 \mu \mathrm{g} / \mathrm{disk}$ for each once. The Amoxycillin / Clavulanic acid disk was placed in the center of the plate, while the three antibiotics disks were placed at distances of 30 $\mathrm{mm}$ ( edge to edge ) from it. The plate was incubated at $37^{\circ} \mathrm{C}$ for 18024 hours, if an enhanced zone of inhibition between either of the cephalosporin antibiotics and the Amoxycillin / Clavulanic acid disk occurred , the test was considered positive .
Detection of quinolone resistance isolates

The bacterial isolates were tested for their susceptibility to ciprofloxacin $10 \mu \mathrm{g} /$ disk , norfloxacin $10 \mu \mathrm{g} /$ disk, and nalidixic acid 30 $\mu \mathrm{g} /$ disk by using standard disk diffusion method ( Bauer et al.,1966 ). All isolates which were resistant to ciprofloxacin are suspected to harbor qnr genes ( Pakzad et al ., 2011 ) .

DNA extraction

Genomic DNA was extracted from all ciprofloxacin resistant isolates using Wizard Genomic DNA purification kit supplemented by (Promega \ USA) according to manufacture instructions. The purity and concentration of genomic DNA were measured using Biodrop spectrophotometer.

\section{Agarose gel electrophoresis}

The method described by Sambrook and Ruseel ( 2001 ), was used for prepare horizontal agarose gel electrophoresis for genomic DNA and PCR product. Agarose at concentration of $0.7 \mathrm{gm} / 100 \mathrm{ml}$ was prepared for genomic DNA, and $1.2 \mathrm{gm} / 100 \mathrm{ml}$ for PCR product

Table (1):Primer used for the amplification of $q n r$ genes .

\begin{tabular}{|c|l|c|c|}
\hline Genes & Oligonucleotides $\left(\mathbf{5}^{\prime} \rightarrow \mathbf{3}^{\prime}\right)$ & Product size & Reference \\
\hline \hline$q n r A$ & $\begin{array}{l}\text { F ATTTCTCACGCCAGGATTTG } \\
\text { R GATCGGCAAAGGTTAGGTCA }\end{array}$ & $516 \mathrm{bp}$ & \multirow{2}{*}{ Pakzad et al ., (2011) } \\
\cline { 1 - 2 }$q n r B$ & $\begin{array}{l}\text { F GATCGTGAAAGCCAGAAAGG } \\
\text { R ACGATGCCTGGTAGTTGTCC }\end{array}$ & $469 \mathrm{bp}$ & \\
\hline$q n r S$ & $\begin{array}{l}\text { F ACGACATTCGTCAACT GCAA } \\
\text { R TAAATTGGCACCCTGTAGGC }\end{array}$ & $417 \mathrm{bp}$ & \\
\hline
\end{tabular}

Table (2): The PCR reaction components $(25 \mu \mathrm{l})$ for genes amplification .

\begin{tabular}{|l|c|}
\hline \multicolumn{1}{|c|}{ Component } & Volume $(\boldsymbol{\mu l})$ \\
\hline \hline GoTaq Green Master Mix (2X) & 12.5 \\
\hline Nuclease Free Water & 9.5 \\
\hline DNA Template & 2 \\
\hline Forward Primer ( 10 picomoles ) & 0.5 \\
\hline Reverse Primer ( 10 picomoles ) & 0.5 \\
\hline Total volume & 25 \\
\hline
\end{tabular}

Table (3). Program conditions for amplification of $q n r$ genes .

\begin{tabular}{|l|c|c|c|}
\hline \multicolumn{1}{|c|}{ Stage } & Temperature ${ }^{\circ} \mathrm{C}$ & Time (min.) & Cycle number \\
\hline \hline Initial denaturation & 94 & 3 & 1 \\
\hline Denaturation & 94 & 1 & \multirow{2}{*}{32} \\
\hline Annealing & 53 & 1 & 1 \\
\hline Extension & 72 & 1 & 1 \\
\hline Final extension & 72 & 7 & 3 \\
\hline Hold & 4 & 3 & \\
\hline
\end{tabular}




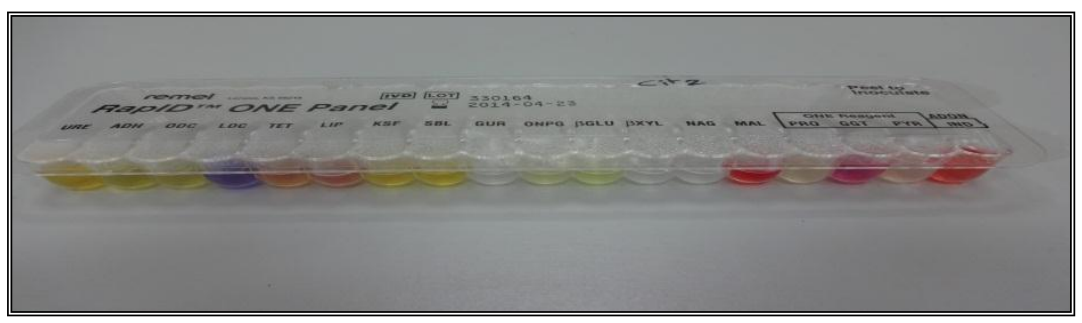

Figure (1): Identification of Citrobacter freundii by RapIDTM ONE panel kit

Table (4): Number and percentage of coliforms spp. isolated from two types of infection

\begin{tabular}{|c|c|c|c|}
\hline \multirow{2}{*}{ Coliforms } & \multicolumn{2}{|c|}{ Type of infection } & \multirow{2}{*}{$\begin{array}{c}\text { Total } \\
\text { No. }(\%) \\
\end{array}$} \\
\hline & UTIs No. (\%) & DFIs No. $(\%)$ & \\
\hline E. coli & $28(50.9)$ & $17(56.7)$ & $45(52.9)$ \\
\hline K. pneumoniae & $17(30.9)$ & $8(26.7)$ & $25(29)$ \\
\hline Ent. cloacae & $2(3.7)$ & $0(0)$ & $2(2.4)$ \\
\hline Ent. aerogenes & $5(9.1)$ & $0(0)$ & $5(5.9)$ \\
\hline C. freundii & $0(0)$ & $2(6.7)$ & $2(2.4)$ \\
\hline Serratia marcescens & $2(3.7)$ & $3(10)$ & $5(5.9)$ \\
\hline Serr.fonticola & $1(1.8)$ & $0(0)$ & $1(1.2)$ \\
\hline Total & $55(64.7)$ & $30(35.3)$ & $85(100)$ \\
\hline
\end{tabular}

Table (5): Fluoroquinolones resistance among coliforms according to types of infection

\begin{tabular}{|c|c|c|c|c|}
\hline \multirow{2}{*}{$\begin{array}{c}\text { Type } \\
\text { of } \\
\text { infections } \\
\end{array}$} & \multirow[b]{2}{*}{ Bacterial isolates } & \multicolumn{3}{|c|}{ Antibiotics } \\
\hline & & $\begin{array}{c}\text { CIP } \\
\text { No }(\%) \\
\end{array}$ & $\begin{array}{c}\text { NOR } \\
\text { No. }(\%) \\
\end{array}$ & $\begin{array}{c}\text { NA } \\
\text { No. }(\%)\end{array}$ \\
\hline \multirow{6}{*}{ UTIs } & E. $\operatorname{coli}(\mathrm{n}=28)$ & $19(67.9)$ & $21(75)$ & $24(85.7)$ \\
\hline & K. pneumoniae $(\mathrm{n}=17)$ & $14(82.4)$ & $14(82.4)$ & $16(94.1)$ \\
\hline & Ent. cloacae $(\mathrm{n}=2)$ & $0(0)$ & $0(0)$ & $1(50)$ \\
\hline & Ent. aerogenes $(\mathrm{n}=5)$ & $3(60)$ & $3(60)$ & $4(80)$ \\
\hline & Serr. marcescens $(\mathrm{n}=2)$ & $1(50)$ & $1(50)$ & $2(100)$ \\
\hline & Serr. fonticola $(\mathrm{n}=1)$ & $0(0)$ & $0(0)$ & $1(100)$ \\
\hline \multirow{4}{*}{ DFIs } & E. $\operatorname{coli}(\mathrm{n}=17)$ & $11(64.7)$ & $12(70.6)$ & $15(88.2)$ \\
\hline & K. pneumoniae $(\mathrm{n}=8)$ & $5(62.5)$ & $5(62.5)$ & $6(75)$ \\
\hline & C. freundii $(\mathrm{n}=2)$ & $2(100)$ & $2(100)$ & $2(100)$ \\
\hline & Serr. marcescens $(\mathrm{n}=3)$ & $2(66.7)$ & $2(66.7)$ & $2(66.7)$ \\
\hline Total & $\mathrm{N}=85$ & $57(67 \%)$ & $60(70.5 \%)$ & $73(85.9 \%)$ \\
\hline
\end{tabular}

Table (6): Number and percentage of ESBLs production among ciprofloxacin resistant coliforms according to types of infection

\begin{tabular}{|c|c|c|c|c|c|}
\hline $\begin{array}{l}\text { Type of } \\
\text { infection }\end{array}$ & $\begin{array}{l}\text { Ciprofloxacin } \\
\text { resistant isolates }\end{array}$ & $\begin{array}{c}\text { Total } \\
\text { No. }\end{array}$ & $\begin{array}{c}\text { Positive ESBL } \\
\text { No. }(\%)\end{array}$ & $\begin{array}{c}\text { Negative } \\
\text { ESBL } \\
\text { No. }(\%) \\
\end{array}$ & $\begin{array}{c}\mathbf{P} \\
\text { values }\end{array}$ \\
\hline \multirow{4}{*}{ UTIs } & E. coli & 19 & $16(84.2)$ & $3(15.8)$ & $0.003^{*}$ \\
\hline & K. pneumoniae & 14 & $8(57.1)$ & $6(42.9)$ & 0.593 \\
\hline & Ent. aerogenes & 3 & $0(0)$ & $3(100)$ & 0.317 \\
\hline & Serr. marcescens & 1 & $0(0)$ & $1(100)$ & 1.000 \\
\hline \multirow{4}{*}{ DFIs } & E. coli & 11 & $9(81.8)$ & $2(18.2)$ & $0.035^{*}$ \\
\hline & K. pneumoniae & 5 & $4(80)$ & $1(20)$ & 0.180 \\
\hline & C. freundii & 2 & $1(50)$ & $1(50)$ & 1.000 \\
\hline & Serr. marcescens & 2 & $0(0)$ & $2(100)$ & 0.564 \\
\hline \multicolumn{2}{|r|}{ Total } & 57 & $38(66.7 \%)$ & $19(33.3 \%)$ & $0.012 *$ \\
\hline
\end{tabular}

* Sig. : $\mathrm{P} \leq 0.05$. 
Table (7) : Number and percentage of $q n r$ genes in ciprofloxacin resistant isolates of coliforms

\begin{tabular}{|l|c|c|c|}
\hline \multirow{2}{*}{ Ciprofloxacin resistant coliforms } & \multicolumn{3}{c|}{ qnr gene types } \\
\cline { 2 - 4 } & qnrA N. (\%) & qnrB N. (\%) & qnrS N. (\%) \\
\hline E. coli $(\mathrm{n}=30)$ & $0(0)$ & $10(33.3)$ & $0(0)$ \\
\hline K. pneumoniae $(\mathrm{n}=19)$ & $0(0)$ & $3(15.8)$ & $0(0)$ \\
\hline Ent. aerogenes $(\mathrm{n}=3)$ & $0(0)$ & $1(33.3)$ & $0(0)$ \\
\hline Serr. marcescens $(\mathrm{n}=3)$ & $0(0)$ & $0(0)$ & $0(0)$ \\
\hline C. freundii $(\mathrm{n}=2)$ & $0(0)$ & $0(0)$ & $0(0)$ \\
\hline Total $(\mathrm{n}=57)$ & $0(0)$ & $14(24.6)$ & $0(0)$ \\
\hline
\end{tabular}

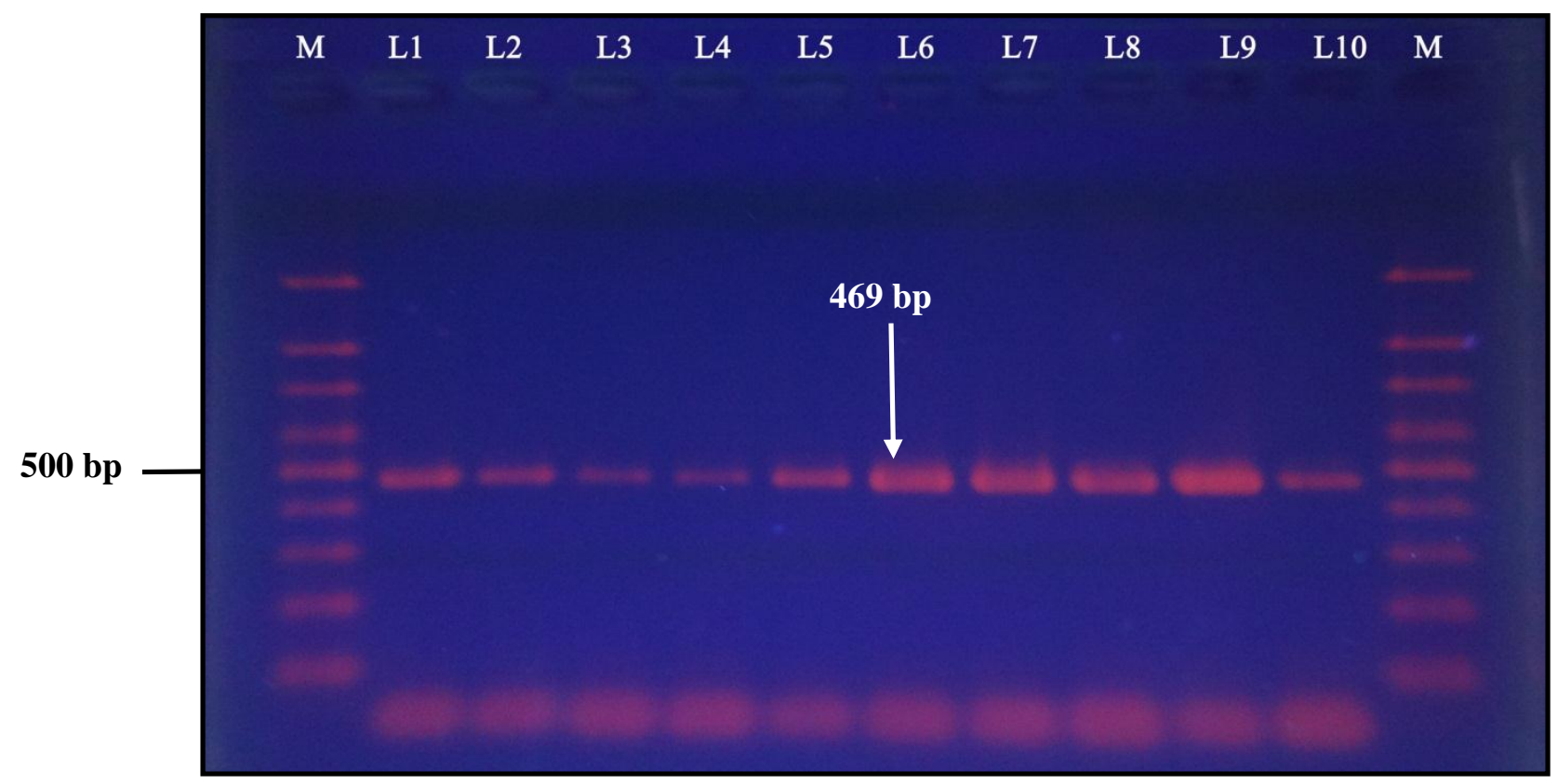

Figure(2): Electrophoresis of PCR amplification of $q n r B$ gene in ESBL- E. coli with expected product length $469 \mathrm{bp}$ in $(1.2 \%)$ agarose gel. $M$ lane, left and right (100bp ladder). Lane 1 - 10 poitive qnrB gene.

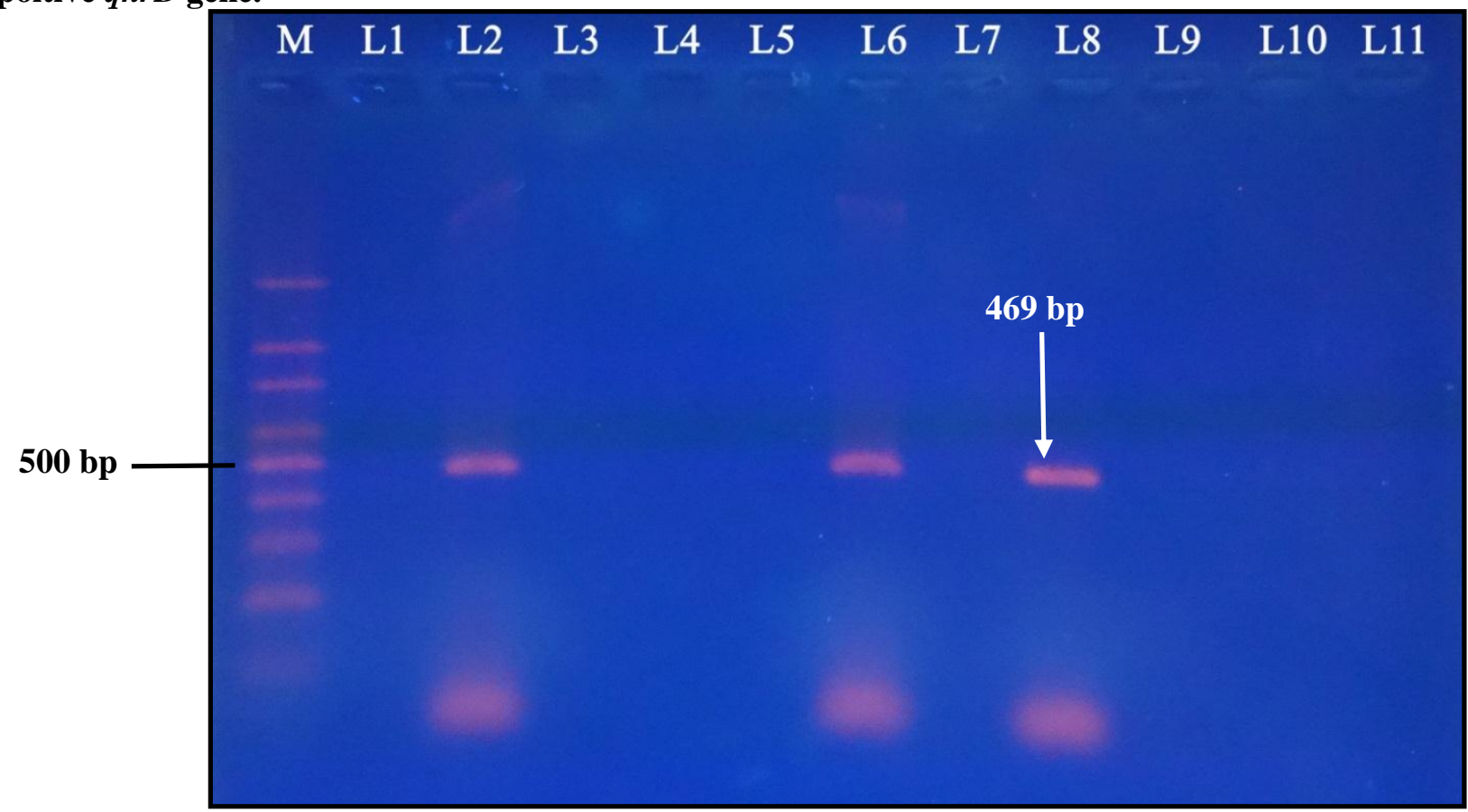

Figure(3): Electrophoresis of PCR amplification of $q n r B$ gene in ESBL- $K$. pneumoniae with expected product length $469 \mathrm{bp}$ in (1.2\%) agarose gel. $M$ lane (100bp ladder). Lane 2,6, and8 positive qnr B gene. 
Table (8): Number and percentage of $q n r$ genes in ESBLs producing and non-producing coliforms.

\begin{tabular}{|l|c|c|}
\hline \multicolumn{1}{|c|}{ qnrB positive isolates } & $\begin{array}{c}\text { ESBLs } \\
\text { N. }(\%)\end{array}$ & $\begin{array}{c}\text { non-ESBLs } \\
\text { N. }(\%)\end{array}$ \\
\hline E. coli $(\mathrm{n}=10)$ & $10(100 \%)$ & $0(0)$ \\
\hline K. pneumoniae $(\mathrm{n}=3)$ & $3(100 \%)$ & $0(0)$ \\
\hline Ent. aerogenes $(\mathrm{n}=1)$ & $0(0)$ & $1(100)$ \\
\hline Total $\mathrm{n}=14$ & $13(92.9)$ & $1(7.1)$ \\
\hline
\end{tabular}

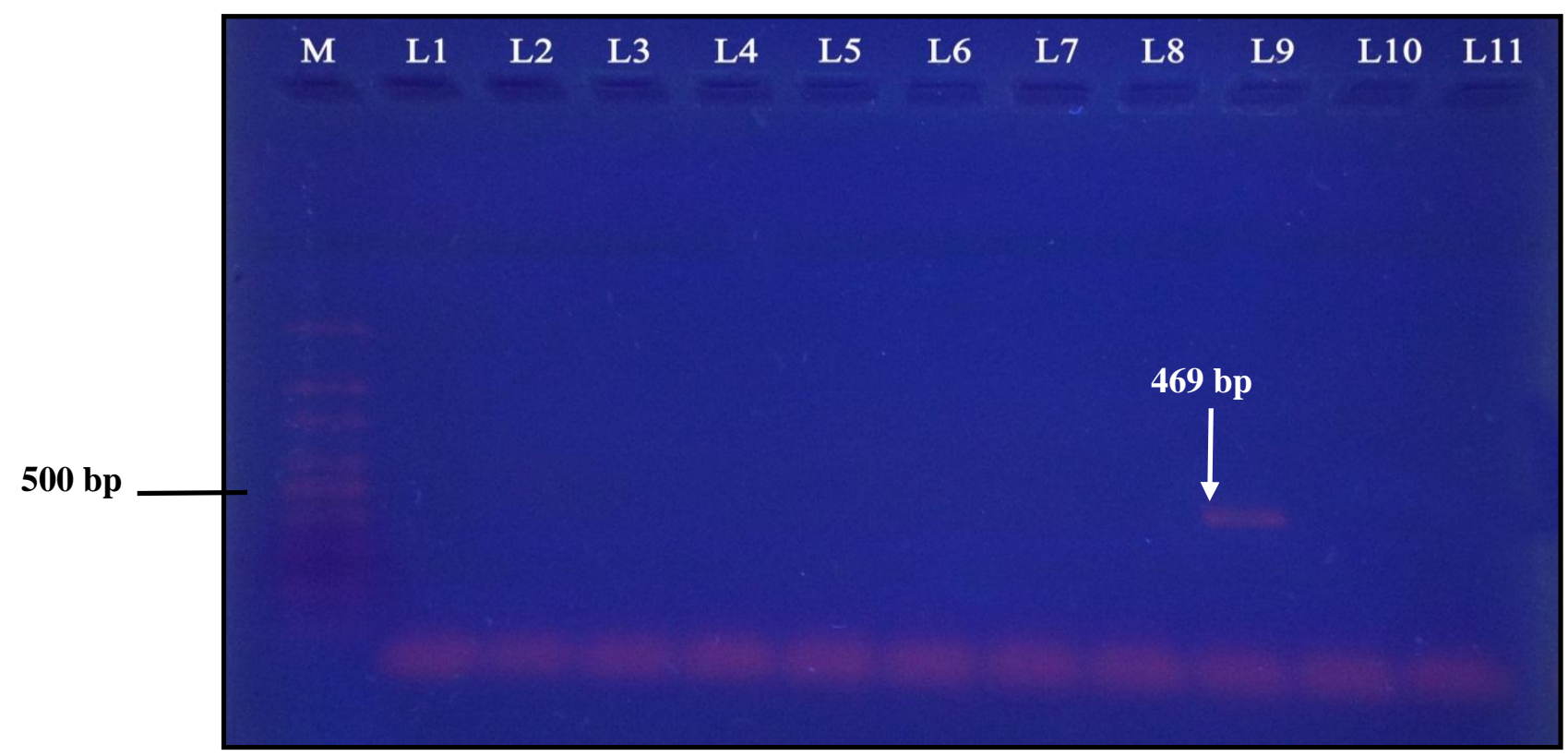

Figure(4): PCR amplification of $q n r B$ gene in non-ESBL coliforms with expected product length 469bp in (1.2\%) agarose gel. $M$ lane (100bp ladder). Lane 9 positive qnrB gene in Ent. aerogenes

\section{DISCUSSION}

\section{Primers used}

Primers sequences were taken from previous articles(Table 1) . All primers were synthesized by Alpha DNA company, CANADA.

\section{Polymerasechain reaction ( PCR ) assay $P C R$ reaction}

All PCR reactions were performed in $25 \mu 1$ volumes in Eppendorf tube . Laminar flow cabinet with UV lamp was used for the preparation of reaction mixture, all the reaction components were prepared separately in ice and used with optimum concentration . The PCR reactions components are shown in (Table 2).

Detection of $q n r A$, $q n r B$, and $q n r S$ genes

PCR conditions program depending on

Pakzad et al ., ( 2011 ), with some modification was used for detection of fluoroquinolones resistance genes as shown in (Table 3 ).

Statistical analysis

All statistical analysis was conducted using the Statistical Package for Social Sciences (S.P.S.S.) version 19 from IBM Company, USA. The $x 2$ test was used for statistical comparison of groups , values $<0.05$ were regarded as significant .

\section{RESULT}

The present study was carried out in $\mathrm{AL}$ Salam General Teaching Hospital and one center for Diabetic Patients at Mosul City , between April 2013 and February 2014 . Out of the total (173) samples collected from both gender , (110) from urinary tact infections (UTIs), and(63) from patients with diabetic foot infections(DFIs ).

Identification of coliforms bacteria was first made by the bacteriological methods, biochemical tests and RapID ${ }^{\mathrm{TM}}$ ONE panel kit was used for accurate identification of isolates at species level (Figure 1). The result showed that the isolated bacteria belonged to five genera ; the number and percentage of coliforms isolated from UTIs and DFIs are listed in (Table 4). The total number of coliform bacteria was (85) isolates, of which UTIs isolates were more frequently encountered $(55 ; 64.7 \%)$ than the DFIs isolates $(30 ; 35.3 \%)$. Among the isolates , Escherichia coli was the predominant isolates 45 $(52.9 \%)$ from clinical samples, $28(50.9 \%)$ were UTIs samples, while $17(56.7 \%)$ were DFIs samples followed by Klebsiella pneumoniae 
which isolated from 25 (29\%) samples 17 (30.9\%) were UTIs samples, and only 8 (26.7\%) were DFIs samples.

The most important coliforms are E. coli, Klebsiella , Enterobacter, and Citrobacter. They can cause many infections like UTIs and wound infections (Dhakal et al ., 2008 and Basavzraj and Jyothi , 2015 ) . In the current study , E. coli $(50.9 \%)$ represented the predominant isolate from UTIs . This finding agrees with other reports in which E. coli was the commonest pathogens isolated from patients with UTIs (Dishvarian , 2010 and Zaki and Elewa, 2015 ).

\section{Fluoroquinolones resistance pattern of coliforms isolates}

Quinolones constitute an important and highly used group of antimicrobial drugs in human and veterinary medicine for a wide variety of microbial infections. Because of wide clinical use, bacterial isolates resistant to quinolone and fluoroquinolone are emerging and spreading rapidly, especially in coliform bacteria ( Guo et al ., 2010 and Saranya et al ., 2013 ). The susceptibility of (85) coliforms spp. against quinolone agents were studied to evaluate the pattern of their resistance using disk diffusion method .

Out of (85) bacterial isolates , 73 (85.9\%) isolates were resistant to nalidixic acid, whereas $60(70.5 \%)$, and $57(67 \%)$ isolates were resistant to norfloxacin and ciprofloxacin respectively(Table 5). This finding was relatively close to that of Ogbolu et al .,(2012) who found that the resistance rate of nalidixic acid among gram-negative bacilli was( $98.3 \%)$, while that for ciprofloxacin was $(76.5 \%)$. Many reports have indicated that the widespread use of fluoroquinolons is contributing to the increasing percentages of fluoroquinolone insusceptible bacterial strains, including coliforms (Namboodiri et al., 2011 and Majumdar et al., 2012).

However, the proportion of E. coli and $K$. pneumoniae isolates that were isolated from UTIs showed highest resistance to fluoroquinolones when compared to those isolated from DFIs .This may be because fluoroquinolones are preferred as initial agents for empiric therapy in UTI, or due to their excellent activity against the pathogens which are commonly encountered in UTIs (Sureshkumar et al ., 2012) .

\section{Phenotypic Extended - Spectrum $\beta$ -} lactamase (ESBLs) detection

The spread of ESBL-producing bacteria has been strikingly rapid worldwide, indicating that continues monitoring systems and effective infection control measures are absolutely required. All ciprofloxacin resistant isolates were tested for their ability to produce the ESBL enzymes using the double disk synergy test (DDST) . This test depends on the synergism that occurs between the clavunate and the cephalosporine, where the clavunate destroys the ESBL and open the way for cephalosporine to exert it's action on bacteria (Ahmed et al., 2013 ).

Out of total (57) ciprofloxacin resistant coliforms tested, 38 (66.7\%) isolates were ESBL producers, while the remaining 19 $(33.3 \%)$ isolates were non-ESBL producers . In the current study, we reported a high incidence of ESBL production among ciprofloxacin resistant $E$. coli strains isolated from UTIs and DFIs (84.2\%), and (81.8\%) respectively, followed by $K$. pneumoniae isolates $(57.1 \%)$ and $(80 \%)$ respectively. Similar to this high result was reported in a study conducted in Nigeria by Alo et al., (2012) who found that (80\%) of ciprofloxacin resistant $E$. coli and $K$. pneumoniae were ESBLs producers. While in contrast, Tolun et al., (2004) who revealed that only $(5.1 \%)$ of the ciprofloxacin-resistant $K$. pneumoniae strains produced ESBL .

It is worthy to note that no ESBL production was observed among the isolates of Ent. aerogenes and Serr. marcescens, whereas only $1(50 \%)$ of the ciprofloxacin-resistant $C$. freundii was ESBLs producers as shown in (Table 6). In contrast, locally other studies are detected the production of ESBL by Ent. aerogenes and Serr. marcescens isolates ( Lafi and Mohammed, 2012 and Tuwajj, 2014 ) .

Molecular detection of $q n r A, q n r B$, and $q n r S$ genes by PCR

Polymerase Chain Reaction (PCR) technique has been used to amplify qnr genes, which may be responsible for flouroquinolones resistance. The PCR analysis showed that among the (57) ciprofloxacin resistant isolates, the $q n r$ genes screened in the present study was present in a total of $14 / 57(24.6 \%)$ isolates as shown in (Table 7). The qnrB gene (469bp) was detected in 10(33.3\%) E. coli, in 3(15.8\%) $\mathrm{K}$. pneumoniae , and in 1(33.3\%) Ent. aerogenes isolates as shown in( Figures 2, 3, and 4). Non of the isolates had qnrA and $q n r S$ type genes in our study .

The prevalence of plasmid-mediated quinolone resistance (PMQR) determinant was investigated in many countries . Tarchouna et al , (2015) found that (32\%) of E. coli strains 
isolated from different clinical samples in a Tunisian hospitals were positive for the presence of $q n r$ genes, and only (12.5\%) of them were carried $q n r B$ gene. Another study conducted in Egypt by EL-Mahdy (2015) who revealed that $(53 \%)$ of E. coli , K. pneumoniae, and Enterobacter spp. were positive for the $q n r$ genes . In China, Wang et al.,(2008) found that the prevalence rates of $q n r$ genes among ciprofloxacin-resistant isolates of $E$. coli and $K$. pneumoniae were $(7.5 \%)$ and (11.9\%) respectively, these rates are lower than our results . Differences in distribution of the $q n r$ genes may be attributed to difference in geographical area, or may be due to difference in selection criteria ( EL-Mahdy, 2015).

The relation between qnrB gene and ESBLs producing and non-producing coliforms:

Resistance to quinolone and fluoroquinolone is often associated with ESBLproducing organisms as well as association with integron carrying $q n r$ genes(Saboohi et al., 2014) The $q n r B$ gene was found in all $(100 \%)$ of ESBL-producing $E$. coli and $K$. pneumoniae isolates as shown in (Figures 2 and 3). This is because the qnr genes are usually associated with the same mobile genetic elements as those of ESBL genes ( Pasom et al., 2013 ) . In Kuwait , Vali et al.,(2015) revealed that (78\%) of $K$. pneumoniae isolates were positive for $q n r B$ gene. Several reports have detected a positive correlation between $q n r B$ gene and the ESBL production (Pakzad et al., 2011 and Goudarzi et al ., 2015).

\section{REFERENCES}

Ahmed, O.I.; El-Hady, S.A.; Ahmed, T.M. and Ahmed, I.Z. (2013). Detection of bla SHV and bla CTX-M genes in ESBL producing Klebsiella pneumoniae isolated from Egyptian patients with suspected nosocomial infections. Egypt J. Med. Hum. Gen., 14: 277-283.

Al-Marjani, M.F.; Kadhim, K.A.; Kadhim, A.A. and Kinani, A. (2015). Ciprofloxacin resistance in Staphylococcus aureus and Pseudomonas aeruginosa isolated from patients in Baghdad. Int. J. Pharm. Sci. Res., 6(2): 382-385.

Alo, M.N.; Anyim, C.; Igwe, J.C. and Elom, M. (2012). Presence of extended spectrum $\beta$ lactamase (ESBL) E. coli and Klebsiella pneumoniae isolated from blood cultures of hospitalized patients. Adv. Appl. Sci. Res., 3(2): 821-825.
Basavzraj, M. and Jyothi, P. (2015). Antibiotic sensitivity pattern of Citrobacter spp. isolated from patients with urinary tract infections in tertiary care hospital in south India. Int. J. Pharm. Pharmace. Sci., 7(1): 252-254.

Bauer, A.W.; Kirby, W.M.M.; Sherris, J.C. and Turck, M. (1966). Antibiotic susceptibility testing by a standardized single disc method. Amer. J. Clin. Pathol., 45: 493496.

Dhakal, B.K.; Kulesus, R.R. and Mulvey, M.A. (2008). Mechanism and consequences of bladder cell invasion by uropathogenic Escherichia coli.Eur. J. Clin. Inv.,38(2):211.

Dishvarian, J.A. (2010). Detection of som bacterial infection in urinary tract and their antibiotic sensitivity. Inter. J. Sci. Tech., 5(3): 21-29.

El-Mahdy, R.H. (2015). Plasmid-mediated quinolone resistance (PMQR) determinants in nosocomial isolates of Enterobacteriaceae. Egypt. J. Med. Microbiol., 24(1): 43-48.

Goudarzi, M.; Fazeli, M.; Azad, M. and Seyedjavadi, S.S. (2015). Prevalence of plasmid-mediated quinolone resistance determinants in extended-spectrum $\beta$ lactamase producing Escherichia coli isolated from patients with nosocomial urinary tract infection in Tehran, Iran. Acta Cir. Bras., 30(2): 71-83.

Guo, Q.; Weng, J.and Wang, M. (2010). A mutational analysis and molecular dynamics simulation of quinolone resistance proteins QnrA1 and QnrC from Proteus mirabilis. BMC Struct. Biol., 10: 33.

Kim, M.H.; Lee, H.J.; Park, K.S. and Suh, J.T. (2010). Molecular characteristics of extended spectrum beta-lactamase in Escherichia coli and Klebsiella pneumoniae and the prevalence of qnr in extended spectrum beta-lactamase isolates in a tertiary care hospital in Korea. Yonsei Med. J., 51(5): 768-774.

Lafi, M.A.K. and Mohammed, S.M. (2012). Novel $\beta$-lactamases in the clinical isolates of Enterobacter spp. and Klebsiella pneumoniae in Ramadi general hospital: A pharmacodynamics study. Iraqi J. Comm. Med., 2: 124- 129.

Lyonga, E.E.; Toukam, M.; Atashili, J.; Gonsu ,H.K.; Adiogo, D.; Mesembe, M.; Nguefack-Tsague, G.; Eyoh, A.; Ikomey, 
G.; Mukwele, B.; Meli, T. J.M. and Okomo, A. M.C. (2014). A comparative study on susceptibility of Enterobacteriaceae to six quinolones in Yaounde. Health Sci. Dis., 14(4): 1-7.

Majumdar, D.; Sharan, H. and Singh, D.N. (2012). Fluoroquinolone resistant Escherichia coli and Klebsiella spp. in community-acquired urinary tract infection in rural Kanpur, India. J. Clin. Diag. Res., 6(6): 978-981.

Namboodiri, S.; Opintan, J.A.; Lijek, R.S.; Newman, M.J. and Okeke, I.N. (2011). Quinolone resistance in Escherichia coli from Accra, Ghana. BMC. Microbiol., 11:44-52.

Ogbolu, D.O.; Daina, O.A.; Ogunledun, A.; Terry, A.O.; Olusoga-Ogbolu, F.F. and Webber, M.A. (2012). Effect of gyrA and parC mutations in quinolones resistant clinical gram-negative bacteria from Nigeria. Afr. $J$. Biomed. Res., 15: 97-104.

Pakzad, I.; Ghafourian, S.; Taherikalani, M.; Sadeghifard, N.; Abtahi, H.; Rahbar, M. and Jamshidi, N.R. (2011). qnr prevalence in extended spectrum Beta-lactamases (ESBLs) and non-ESBLs producing Escherichia coli isolated from urinary tract infections in central of Iran. Iran. J. Basic. Med. Sci., 14(5): 458-464.

Pasom, W.; Chanawong, A. and Lulitanond, A. (2013). Plasmid-mediated quinolone resistance genes, aac(6')-Ib-cr, qnrS , qnrB , and $q n r A$, in urinary isolates of Escherichia coli and Klebsiella pneumoniae at a teaching hospitals, Thailand. Jpn. J. Infect. Dis., 66: 428-432.

Raei, F.; Eftekhar, F. and Feizabadi, M.M. (2014). Prevalence of quinolone resistance among extended-spectrum $\beta$-lactamase producing uropathogenic Klebsiella pneumoniae. Jundishapur J. Microbiol., 7(6): 1-5.

Rushdy, A.A.; Mabrouk, M.I.; Abu-Sef, F.A.; Kheiralla, Z.H.; Abdell-All, S.M. and Saleh, N.M. (2013). Contribution of different mechanisms to the resistance to fluoroquinolones in clinical isolates of Salmonella enterica. Braz. J. Infect. Dis., 17(4): 431-437.

Saboohi, R.; Rajaei, B.; Rad, N.; Razavi, M.; Aghasadeghi, M.; Moshiri, A.; Bahremand, A.R.; Kava, K.; Zangeneh, M.; Rahbar, M.; Sarvestani, S.K. and Siadat, S.D. (2014). Molecular detection and association of qnrA, $q n r B$, qnrS, and blaCMY resistance genes among clinical isolates of Salmonella spp. in Iran. Advan. Microbiol., 4: 63-68.
Sambrook, J. and Russell, D. W. (2001). Molecular cloning: a laboratory Manual. 3rd ed., vol. 1. Cold Spring Harbor Laboratory Press, Cold Spring Harbor, NY.

Saranya, K.; Pavulraj, S.; Kalaiselvi, L.; Amasaveni, S. and Ramesh, S. (2013). Antibacterial susceptibility profiles of coliforms isolated from bovine subclinical and clinical mastitis against fluoroquinolones. Tamilnadu J. Vet. Anim. Sci., 9(4): 279-284.

Sureshkumar, M.; Gopinathan, S.; Rajesh, K.R. and Priyadharsini, I. (2012). Prevalence of ciprofloxacin resistance among gram-negative bacilli in a tertiary care hospital. J. Clin. Diag. Res., 6(2): 180-181.

Tarchouna, M.; Ferjani, A.; Marzouk, M.; Guedda, I. and Boukadida, J. (2015). Prevalence of plasmid-mediated quinolone resistance detrminants among clinical isolates of Escherichia coli in a Tunisian hospitals. Int. J.Curr.Microbiol. App.Sci.,4(3):195-206.

Tarchouna, M.; Ferjani, A.; Marzouk, M.; Guedda, I. and Boukadida, J. (2015). Prevalence of plasmid-mediated quinolone resistance detrminants among clinical isolates of Escherichia coli in a Tunisian hospitals. Int. J. Curr. Microbiol. App.Sci.,4(3):195-206.

Tolun, V.; Kucukbasmaci, O.; Torumkuney, D.; Catal, C.; Ang, M. and Ang, O. (2004). Relationship between ciprofloxacin resistance and extended-spectrum $\quad \beta$-lactamase production in Escherichia coli and Klebiella pneumoniae strains. Cli. Microbiol. Infect., 10: $72-75$.

Tuwaij, N.S.S. (2014). Phenotypic and molecular characterization of ESBLs produced by Serratia marcescens isolates in Najaf hospitals. Ph.D. Thesis. University of Kufa. Iraq.

Vali, L.; Dashti, A.A.; Jadaon, M.M. and ElShazly, S. (2015). The emergence of plasmid mediated quinolone resistance qnrA2 in extended spectrum $\beta$-lactamase producing Klebsiella pneumoniae in the Middle East. DARU J. Pharm. Sci., 23: 34-39.

Wang, A.; Yang, Y.; Lu, Q.; Wang, Y.; Chen, Y.; Deng, L.; Ding, H.; Deng, Q.; Zhang, H.; Wang, C.; Liu, L.; Xu, X.; Wang, L. and Shen, X. (2008). Presence of qnr gene in Escherichia coli and Klebiella pneumoniae resistant to ciprofloxacin isolated from pediatric patients in China. BMC. Infect. Dis., 8(68): 1-6.

Zaki, M. and Elewa, A. (2015). Evaluation of uropathogenic virulence genes in Escherichia coli isolated from children with urinary tract infection. Int. J. Adv. Res., 3(3):165-173. 